\title{
Design and Development of Agricultural Spraying Drone: A Review
}

\author{
Shantanu D. Munghate ${ }^{1}$ I Dr. Prashant S. Kadu ${ }^{1}$ \\ ${ }^{1}$ Department of Mechanical Engineering, AGPCE Nagpur, Nagpur, Maharashtra, India
}

To Cite this Article

Shantanu D. Munghate and Dr. Prashant S. Kadu, "Design and Development of Agricultural Spraying Drone: A Review", International Journal for Modern Trends in Science and Technology, 6(8): 240-246, 2020.

Article Info

Received on 21-July-2020, Revised on 04-August-2020, Accepted on 12-August-2020, Published on 18-August-2020.

\section{ABSTRACT}

Designing the drone for spraying has become one of the essential concerns in recent developments in technology in order to avoid human involvement in the spraying phenomenon. While designing the spraying drone it is important to design the components according to according to specifications. In this paper a tank carrying a spraying liquid of $3 \mathrm{lt}$. for spraying herbicide over rice crop. This paper deals with the selection of spraying liquid and spraying system required for the spraying operation. The spraying system includes the pump, nozzle and carrying media(pipes). The spraying tank is analyzed for drag and lift at different angles of the front face is titled at different angles between 0 to $60^{\circ}$ with the vertical. The optimum tank configuration has been selected for the design. The paper also includes selection of herbicide, pump and nozzles for the drone spraying assembly.

KEYWORDS: UAV, Drone, spraying, nozzle, herbicide

\section{INTRODUCTION}

70 years has passed when the term Green Revolution was introduced in India, which involved use of modern technology like genetically engineered or hybrid crops, use of chemical or bio-fertilizers, use of pesticides, herbicides, plant nourishment and growth regulators and new irrigation techniques for improving crop yield. The development continues as of today and will continue to the points were needs are met. Even when modernization in the field of agriculture has started in India in late 60's, the Indian farmer is still under a lot of duress because of cost and ill effects of certain methods. One of such method is agricultural spraying. Agricultural spraying involves spraying of liquid pesticides, herbicides, fertilizers etc. and still involves a manual labor in direct vicinity or contact with the spray. As per the varying height of flora and protection used by farmer is concerned the inhalation capacity and effect on body has varying degree of ill effects. Protective measures during and after pesticide application are considered effective means of reducing the risks of farmer's health. [1]

Table 1.1 Protection and Farmers

\begin{tabular}{|c|c|}
\hline $\begin{array}{l}\text { Actions and precautions that } \\
\text { were employed by farmers }\end{array}$ & $\begin{array}{l}\text { Percentag } \\
\text { e } \\
\text { Involvement }\end{array}$ \\
\hline $\begin{array}{l}\text { Farmers which used sticks to mix } \\
\text { pesticides }\end{array}$ & $65.5 \%$ \\
\hline $\begin{array}{l}\text { Farmers which used bare hands } \\
\text { for mixing }\end{array}$ & $22.22 \%$ \\
\hline $\begin{array}{l}\text { Farmers who claimed to wash } \\
\text { their hands with soap after using } \\
\text { pesticides }\end{array}$ & $93.57 \%$ \\
\hline $\begin{array}{l}\text { Farmers who were aware that } \\
\text { protective equipment had to be used } \\
\text { while using pesticides. }\end{array}$ & $74 \%$ \\
\hline Farmers who used Face mask & $58.48 \%$ \\
\hline
\end{tabular}




\begin{tabular}{|c|l|}
\hline Farmers who used hand gloves & $15.79 \%$ \\
\hline $\begin{array}{l}\text { Farmers who used hand pump to } \\
\text { spray pesticides while the rest used } \\
\text { hand }\end{array}$ & $77 \%$ \\
\hline
\end{tabular}

There are many technologies available for spraying including Backpack (Knapsack) Sprayer, Lite-Trac, Motorcycle Driven Multi-Purpose Farming Device and Aerial Sprayer.[2]

Modern agriculture relies on technology and fair share of such technology is involved in Indian agriculture too. Agriculture spraying have proved

\section{LITERATURE REVIEW}

Bruno S. Faiçal (20) [3] In this paper states the importance of fertilizers and pesticides in agricultural field to increase crop yield. Many problems occur while spraying pesticides in field, like intensity and direction of wind. To overcome such problem author has described an architectural design like self-alignment of drone route while spraying in field. They give the technique which is helpful for drone to adjust its direction according to direction and intensity of wind. This process of spraying of chemicals is managed by wireless sensors network (WSN). They also solved the problem of route for drone and also the impact of high number of messages received between WSN and drone. The spraying of chemical $\approx 14 \%$ can be improved by exchanging messages in $10 \mathrm{~s}$ when compared to $\approx 27 \%$ when sets of messages exchanged in $30 \mathrm{~s}$.

Catur Aries Rokhmana (20) [4] Author states that the drone which is cost-effective, fast in producing, convenient for use and good design. This type of drone can be useful for agriculture land development, vegetation monitoring, plant health. Photogrammetric drones are very useful for visualization, measuring parcel area, trees or plant monitoring. This system contains Orthophoto image and digital elevation model (DEM). Author states that this system uses $\mathrm{R} / \mathrm{C}$ aeromodelling plane which carries digital pocket camera to get visual images. This drone used to identify vegetation or tree structure.

UM Rao Mogili (20) [5] India is the agricultural country whose main source of economy depend of the farmers over $70 \%$ of the people in rural area belongs to agricultural field. Agricultural field faces my problems like unfavorable weather conditions, pests and insects which lower the yield of the crops. Due to manual spraying of chemicals nearly one million cases of ill effected person were registered in WHO. To overcome problems like this author to be a boon for crops. These spraying liquids have a hazardous effect on famers and labors because of the use of conventional and traditional method since it involves direct contact with these harmful spray contents. This paper will provide an insight into the UAV used for agricultural spraying. This paper will also make an attempt to review various spraying configurations with respect to the drones and their effect on spraying operation. The paper also searches for different components and materials used in drones in order to find a suitable material.

proposed the used of drone for spraying, this will reduce the side effect of chemicals and saves the time. Author conclude that using of drone in agricultural field have many applications like easy and faster spraying of pesticides in the field. By using its multispectral camera monitoring of crop is also easy due to this we can find the area where we have to spray pesticides.

He Xiongkui, Jane Bonds et al (2017) [6] According to the author use of drone for spraying of pesticides gives good results in East Asian Countries like South Korea, Japan, China. These Unmanned vehicles are easy to handle and low in cost when compared to old manned aerial operations. In this paper author gives the comparison of spraying and protection of plant with the help of drone in China, Japan and South Korea.

Misbah Rehman.z, et al (2016) [7] Author stated that the use of drone in spraying of pesticides is common because of speed and effectiveness. Manual spraying has more disadvantages i.e. it may lower crop yield or cause damage to the crops. The quad copter drone has great application in spraying of pesticides which overcomes the ill-effects of pesticides in human being. Authors conclude that drones are cheaper and easy to operate. They can also be used to spray at hilly area. It can take place of nearly 50 labors and save their lives and also saves so much time.

MeivelM.E,et al (2016) [8] Author stated that to increase the production of crops frequent spraying of chemical and fertilizers is necessary. According to WHO in developing countries 1 million pesticide cases come from which one lakh deaths in each year occurs. To avoid the pesticide, poison the spraying can be done by using drones. The drone is automated and sprayer is triggered by $R F$ controlled Nozzle. This sprayer module can easily access the area which cannot be accessed by humans. These drones can spray solid as well as liquid material also. This drone also helps to 
reduce pollution when spraying is done from a low altitude and also has great application of management of pest and vectors.

He Luo, eta al (2017) [9] According to the author while spraying chemicals in the field using drones the main factor is to give task allocation to the drone. In this paper author is introducing the drone kinetics. Author analyzed two factors tempura in which pesticides is spraying and the times needed for pesticides spraying. Genetic algorithm of the author used to solve the variable time window and variable profits model. The allocation of tasks to drone is basically flight trajectory planning. Author discussed about the DTOP-VTW-VP model which gives allocation tasks to the spraying drones. The model analyzes the Dubins path and regular TOP and by determining time window it sprays pesticide according to temperature.

M. Zahir Ahmed, et al (201) [10] Author stated that drones are the flying devices which are autonomously programmed. In this paper author discussed about the use of the autonomously flying vehicle in the field of agriculture and precision farming. The Internet of Thing (IOTs) can help small to big scale farmers. Author discussed about the various agricultural area where we employ drone for good results. The use of drone will increase the yield and reduce the time. As this drones need less energy it is energy efficient because the most of the IOT equipment need more amount the energy as compared to this drones.

Spoorthi.S et al (201) [11] In this paper author proposed a new model known as FREYR drone which can be used in the process of spraying of pesticides in farm. Android app can be used to control this type of drone \& too, that can be connected to the Wi-Fi (ESP8266) i.e. interfaced in the drone. The drone consists of wireless camera which helps to transmit and receive pictures by giving high resolution. The open source electronics prototype platform named as Arduino Board is used here; Wi-Fi and GPS are interfaced here. ACCELEROMETER,GYRO (MPU 6050), MAGNETOMETER(HMC 5883L) have been used to balance the directions and orientations.

Bruno S. Facial et al (2014). [12] According to author the large-scale production quality can be maintained by using essential pesticides in the agriculture. Spraying speeds up the process. When spraying is done precision is increased, used amount of pesticide can be reduced and agricultural quality of the product can be improved too as well as chances of environmental damage can be mitigated. The methodology of fine-tuning of control rules the drift of pesticides can be reduced. Here the investigation is based on the methodology of Particle Swarm Optimization. Experimentally they have evaluated optimization method.

Ajay Emmanuel A et al (2017) [13] Author stated in the paper about Quad copter for the purpose of agriculture. Agriculture producers improve productivity and efficiency to maintain their profit margins to help them machines are developed which was the aim of this project. To identify the infected crops and water flow on the field the Onboard camera is interfered with flying Quad copter. Microcontroller (Atmel 164 IC) are used for the sensors signals and to control the motors output form controller board are used. The gain values for the control of drone are essential and specific values are needed depending upon the size and structure of drone hence, adjustment of gain value for stable flight and obtaining those values using control equations is necessary.

S.R.Kurkute et al (2018) [14] According to author to reduce the human efforts new and different types of technologies has been introduced in various ways in the field of Agriculture for the detection of pest's presence, UREA spraying, etc. Quad copter UAV and the spraying mechanism's development is described in this paper. Agriculture Drone is used in the industry purpose for farming. By using the drone completelyone can continuously perform the spraying work and as compared to human reduces the time too. Drone uses 3watt of power that charged 10/- rupees only for per day. Hence, drone uniformly sprays the pesticides. The design for Drone system for the purpose of Agriculture is the mainly described in the entire paper. Too the advantages and disadvantages are discussed here.

Suraj Shetty et al (2018) [15] Author stated that spraying of harmful pesticides can affect the health of farmers. To overcome this problem easily operated drone (quad copter) have been developed for the farmers. For the particular rate of nozzle $=2.439 \mathrm{~m} 3 / \mathrm{sec}$ the sprayed is $400 \mathrm{ml}$, time taken for spraying is $190 \mathrm{sec}$, discharge time is $2.1 \mathrm{~m} 3 / \mathrm{sec}$ and battery consumption is $0.25 \mathrm{mV}$. It may lead to health damage of the farmers so this technology worthily helps the farmers to stay away from the harmful pesticides. The physically challenged farmers or persons too can easily use this technology to spray the pesticide. The productivity of the farming leads to an improvement if there will be advancement in the 
technology. For the enhancement in the growth of the crops this technology provides the effective way and efficient way.

Hang Zhu et al (2017) [16] According to author with developed software sprayer for agriculture is developed using a TL494 with fixed- frequency where Pulse Width Modulation (PWM) is the controller for the Unmanned Aerial Vehicle(UAV).In the production of cropping areas spray application, pesticide applications are used in high precision this was the result shown by the PWM controller. Control voltage and Duty Cycle, Flow Amount and Duty Cycle they have their strong correlation that indicates the PWM controller. Application of pesticides enhances the efficiency for the development of a PWM controller that has a great potential.

Yallappa D. et al (2017) [17] According to author the construction of Mounted Sprayer contains BLDC motors, LiPo (Lithium polymer) batteries,etc. He used 6BLDC motors those were mounted to hexa-copter frame to lift of $5 \mathrm{~kg}$ payload capacity. For the propulsion system there is the requirement of the released current of Two LiPo batteries of 6 cell- $8000 \mathrm{mAh}$.To hold the pesticide solution a 5liter capacity conical-square shaped fluid tank was used. To pressurize the spray liquid a $12 \mathrm{~V}$ DC motor coupled with pump was used; by the means of four nozzles fine droplets were atomize. The drone was entirely mounted with transmitter at ground level to monitor the live spraying operation there was HD FPV camera at front down side of the drone sprayer. With increase in the height and operating pressure of the spray the uniformity of the spray was increased.

It makes the spraying job easier and faster too boosts chemical effectiveness.

R.Ilakiya et al [18] The author proposed the spraying of urea in the agricultural field by using the quad-rotor model. Its use in the field for the short period of time increases the productivity and reduces the labor work. Too, improvement in the weight lifting capacity of the UAV improvement is produced by this paper. As per future situations it can be used in different terms, conditions and strategies. Too it is effortless due to the presence of camera transmitter.

Fabrizio Sarghini et al (2017) [19] The author stated in this paper that drones in agriculture are used for multiple tasks, mainly to increase crop yields, monitoring farm and consuming less time,labor-work and resources. The specified tasks are also done by medium size drone like spraying of pesticide or fertilizer. For development of UAVs of payload equal to $26 \mathrm{~kg}$ and estimated flying time is $23 \mathrm{~min}$ can be possible in today world with latest technology. One of difficult challenge is plantation or pesticide distribution. It results about simplified theories on standard configurations to improve design of heavy lift multirotor for agriculture uses like payload and flight envelope.

Vikram Puri et al (2017) [20] In this paper author told the importance of drones in field and investigated top drones available in today's world for monitoring and yielding better crop quality and preventing damage to crop and field. This study looks at different drone application in the field of agriculture. This study has also found out the commercially available drones for agricultural application. One of such models is Agars MG-1-DJI can cover 4000 to $6000 \mathrm{~m} 2$ area in 10 minutes and 70 times faster than manual spraying.

Mr. I. D. Pharne et al (2018) [21] The paper states the current stature use of pesticide and methods incorporated to spray them which brings the author to the use of UAVs for the spraying which is less hazardous as compared to the traditional methods. Which brings the author to the use of such UAVs in spraying and he made an attempt to design such UAV for the purpose of spraying. Author found out that for quality and handling large weight pesticides it is necessary to select a high rated BLDC motors which also requires high rated LiPo battery to increase flight time which result in increase of overall weight carry by the UAV and hence a proper balance between payload pesticides weight and UAVs components is very much essential.

Bruno S. Faiçal et al (2017) [22] In this paper author suggested some advice on spraying process done by UAVs and wires less sensor networks (WSN) are better as well as safer than manned agriculture aircraft. Due to some sudden change in environment like change in wind speed and direction to solve this problem author suggest computer based system able to control UAV rules.by use of ground control station to run through route with more specific deposition of pesticide and less environmental damage.

Madhu K N et al (201) [23] Author stated that Quad Copter is used to splash the pesticide all over. Quad copter UAV advancement is shown here and mixing of sprayer module is examined here. By using GPS Quad Copter can be made autonomous. They are sprayed in a manner like from lower altitude due to which there will be reduction in environmental pollution. 
Nitish Das et al (2015) [24] According to author spraying devices is mechanized in such a way that there is equal distribution of fertilizers and pesticides into the farm due to which the cost production reduces hence farmers are still using same old tradition of spraying by carrying backpack sprayer those are spread manually. To spray number of pesticides, herbicides, fungicides and defoliants sprayers are used commonly

\section{Discussion}

A review of frame materials and tank capacities is also conducted in order to evaluate most commonly used material.

Table 3.1 Frame Sizes and Drone Configuration for spraying drone used in different papers

\begin{tabular}{|c|c|c|c|}
\hline Sr No. & Author name & $\begin{array}{l}\text { Drone } \\
\text { type }\end{array}$ & $\begin{array}{l}\text { Frame } \\
\text { Material }\end{array}$ \\
\hline 1 . & $\begin{array}{l}\text { Yallappa, D., } \\
\text { et al[17] }\end{array}$ & $\begin{array}{l}\text { Hexacopte } \\
\mathrm{r}\end{array}$ & $\begin{array}{l}\text { Aluminiu } \\
\mathrm{m} \text {, glass } \\
\text { fiber }\end{array}$ \\
\hline 2. & $\begin{array}{l}\text { P, V. S. R. et } \\
\text { al[25] }\end{array}$ & $\begin{array}{l}\text { Quadcopt } \\
\text { er }\end{array}$ & $\begin{array}{l}\text { Allumini } \\
\text { um }\end{array}$ \\
\hline 3. & $\begin{array}{l}\text { I. D. Pharne et } \\
\text { al[21] }\end{array}$ & $\begin{array}{l}\text { Quadcopt } \\
\text { er }\end{array}$ & $\begin{array}{l}\text { Glass } \\
\text { fiber }\end{array}$ \\
\hline 类 & $\begin{array}{l}\text { Karan Kumar } \\
\text { Shaw et al[26] }\end{array}$ & $\begin{array}{l}\text { Octacopte } \\
\mathrm{r}\end{array}$ & $\begin{array}{l}\text { Carbon } \\
\text { fiber }\end{array}$ \\
\hline 5 . & $\begin{array}{l}\text { Rahul Desale } \\
\text { et al[27] }\end{array}$ & $\begin{array}{l}\text { Quadcopt } \\
\text { er }\end{array}$ & PVC pipe \\
\hline & $\begin{array}{l}\text { Vikrant } \\
\text { Krishna } \\
\text { Suryawanshi } \\
\text { et al[28] }\end{array}$ & $\begin{array}{l}\text { Quadcopt } \\
\text { er }\end{array}$ & $\begin{array}{l}\text { Aluminiu } \\
\mathrm{m}\end{array}$ \\
\hline 7. & $\begin{array}{c}\text { Shaik. Khamu } \\
\text { ruddeen et } \\
\text { al[29] }\end{array}$ & $\begin{array}{l}\text { Quadcopt } \\
\text { er }\end{array}$ & $\begin{array}{l}\text { Aluminiu } \\
\mathrm{m}\end{array}$ \\
\hline 8. & $\begin{array}{c}\text { Matsuura, F et } \\
\text { al[30] }\end{array}$ & $\begin{array}{l}\text { Octacopte } \\
\mathrm{r}\end{array}$ & $\begin{array}{l}\text { Aluminiu } \\
\mathrm{m}\end{array}$ \\
\hline 9. & $\begin{array}{c}\text { Tejas S. Kabra } \\
\text { et al }[31]\end{array}$ & $\begin{array}{l}\text { Quadcopp } \\
\text { ter }\end{array}$ & $\begin{array}{l}\text { Aluminiu } \\
\mathrm{m}\end{array}$ \\
\hline
\end{tabular}

Table 3.2 Tank Sizes and Drone Configuration for spraying droneused in different papers

\begin{tabular}{|r|l|l|l|}
\hline Sr No. & Author name & Drone type & $\begin{array}{l}\text { Tank } \\
\text { size }\end{array}$ \\
\hline 1. & $\begin{array}{l}\text { Yallappa, D., } \\
\text { et al[17] }\end{array}$ & Hexacopter & $\begin{array}{l}5.5 \\
\text { litres }\end{array}$ \\
\hline 2. & $\begin{array}{l}\text { Wen, S et } \\
\text { al[32] }\end{array}$ & Quadcopter & $\begin{array}{l}10 \\
\text { litres }\end{array}$ \\
\hline 3. & $\begin{array}{l}\text { Y. Huang et } \\
\text { al[33] }\end{array}$ & Quadcopter & $5 \mathrm{Kg}$ \\
\hline 4. & $\begin{array}{l}\text { P, V. S. R. et } \\
\text { al[25] }\end{array}$ & Quadcopter & $1.8 \mathrm{Kg}$ \\
\hline 5. & $\begin{array}{l}\text { R. Nivas et } \\
\text { al[34] }\end{array}$ & Quadcopter & 1 litre \\
\hline
\end{tabular}

\begin{tabular}{|c|c|c|c|}
\hline 6. & $\begin{array}{l}\text { Vihari, M et } \\
\text { al[35] }\end{array}$ & Quadcopter & $\begin{array}{l}250 \\
\mathrm{ml}\end{array}$ \\
\hline 7. & $\begin{array}{l}\text { Karan } \\
\text { Kumar Shaw } \\
\text { et al[26] }\end{array}$ & Octacopter & $\begin{array}{l}6 \\
\text { litres }\end{array}$ \\
\hline 8. & $\begin{array}{l}\text { Vikrant } \\
\text { Krishna } \\
\text { Suryawanshi } \\
\text { et al[28] }\end{array}$ & Quadcopter & 1 litre \\
\hline 9. & $\begin{array}{l}\text { Thomas } \\
\text { Anken et } \\
\text { al[36] }\end{array}$ & $\begin{array}{l}\text { Hexacopter } \\
\text { (Huanaco } \\
\text { AG-V6A), } \\
\text { octacopter } \\
\text { (Agras DJI } \\
\text { MG-1) }\end{array}$ & $\begin{array}{l}15.2 \\
\mathrm{Lt}, \\
10 \mathrm{Lt} .\end{array}$ \\
\hline 10. & $\begin{array}{l}\text { S.Meivel } \\
\text { M.E. et al[8] }\end{array}$ & quadcopter & $4.4 \mathrm{~kg}$ \\
\hline 11. & $\begin{array}{l}\text { Matsuura, F } \\
\text { et al[30] }\end{array}$ & Octacopter & $2 \mathrm{~L}$ \\
\hline 12. & $\begin{array}{l}\text { Tejas S. } \\
\text { Kabra et } \\
\text { al[31] }\end{array}$ & Quadcoppter & \\
\hline 13. & $\begin{array}{l}\text { Tang, Y et } \\
\text { al[37] }\end{array}$ & Quadcopter & $15 \mathrm{~L}$ \\
\hline & $\begin{array}{l}\text { Qin, W et } \\
\text { al[38] }\end{array}$ & Quadcopter & \\
\hline 15. & $\begin{array}{l}\text { Saddam } \\
\text { Hussain et } \\
\text { al[39] }\end{array}$ & Hexacopter & $15 \mathrm{~L}$ \\
\hline
\end{tabular}

It can be observed from the reviewed literature that there are several technologies available with spraying drone. There is a lot of struggle with low battery support. This can be optimized by replacing the battery technology by an alternative power source which should have high discharge, less weight and a larger capacity. Until such technology develops one should focus on designing the drone with as optimality as possible.

The tables show the use of drone configuration with respective tank size and frame material according to the reviewed literature it can be said that

1. For low capacity sprayer carbon fiber is a superior alternative to that ofAluminium and a balance should be drawn between number of rotors used and the payload in such a way that addition of weight due to rotors and supporting architecture will not overburden the battery, should not make the drone bulky, should not add weight where the work can be easily achieved by lesser number of rotors and should be easy to maneuver.

2. The number of rotors used increase with the weight of payload and hence the supporting architecture should be strong enough to support the increasing load or the design 
should be modified.

3. A special attention should be given to aerodynamic design of drone frame and the tank as they are the component with largest surface area.

\section{Conclusion}

The following conclusions can be drawn from the above review:

1. It is essential to design a drone which is structurally as well as aerodynamically optimized i.e. they should sustain a wider range of stresses as well as are less susceptible to drag forces.

2. The spraying tank which is the payload to be carried by drone assembly should also be aerodynamically and structurally stable.

3. An effective control mechanism is necessary to handle the external disturbances due to wind and different external forces as well as the control mechanism should account for internal liquid loads and internal unbalances.

4. Drones with evolving technologies can prove to be a worthy asset in precision agriculture.

\section{REFERENCES}

[1] Minnikanti Venkata Satya Sai, G Devi Revati, R Ramya, Ann Mary Swaroop, Eswaran Maheswari, Mudigubba Manoj Kumar , "Knowledge and perception of farmers regarding pesticide usage in a rural farming village, Southern India" IJOEM Vol. 23 issue 1 India.

[2] Das N., Khawas V., Maske N., Chaudhary S. K. April 2019, "Agricultural Fertilizers and Pesticides Sprayers - A Review" IJIRST Vol. 1 issue 11 India.

[3] Bruno S. Faiçal," The use of unmanned aerial vehicles and wireless sensor networks for spraying pesticides" Journal of Systems Architecture http://dx.doi.org/10.1016/j.sysarc.2014.01.004

[4] Catur Aries Rokhmana," The potential of UAV-based remote sensing for supporting precision agriculture in Indonesia" The 1st International Symposium on LAPAN-IPB Satellite for Food Security and Environmental Monitoring doi: 10.1016/j.proenv.2015.03.032

[5] UM Rao Mogili," Review on Application of Drone Systems in Precision Agriculture" International Conference on Robotics and Smart Manufacturing (RoSMa2018) doi 10.1016/j.procs.2018.07.063

[6] He Xiongkui, Jane Bonds et al," Recent development of unmanned aerial vehicle for plant protection in East Asia" International journal of Agriculture and Bio Engineering $\begin{array}{lllllll}\text { Vol } & 10 & \text { No.3 } & 18 & \text { may } 2017 & \text { DOI: }\end{array}$ $10.3965 /$ j.ijabe.20171003.3248.

[7] Misbah Rehman.Z, et al," Quadcopter for pesticide spraying" International Journal of Scientific \& Engineering Research, Volume 7, Issue 5, May-2016

[8] MeivelM.E,et al," Quadcopter UAV Based Fertilizer and Pesticide Spraying System" International Academic
Research Journal of Engineering SciencesVol. no.1 issue no 1, February 2016, Page No.8-12

[9] He Luo, eta al ," Optimization of Pesticide Spraying Tasks via Multi-UAVs Using Genetic Algorithm" Hindawi Mathematical Problems in Engineering Volume 2017,16 pages https://doi.org/10.1155/2017/7139157

[10] M. Zahir Ahmed, et al," IoT based Smart Automation using Drones for Agricultures" International Journal of Scientific Development and Research (IJSDR) Volume 3, Issue 1.

[11] Spoorthi.S et al," Freyr Drone: Pesticide/Fertilizers Spraying Drone - An Agricultural Approach"

[12] Bruno S. Facial et al, "Fine-tuning of UAV control rules for spraying pesticides on crop fields" 2014 IEEE 26th International Conference on Tools with Artificial Intelligence DOI 10.1109/ICTAI.2014.85

[13] Ajay Emmanuel A et al; "Fertilizer Spraying Quadcopter using Arduino UNO" IJSTE - International Journal of Science Technology \& Engineering | Volume 3 | Issue 09 | March 2017 ISSN (online): 2349-784X

[14] S.R.Kurkute et al, " Drones for Smart Agriculture: A Technical Report” International Journal for Research in Applied Science \& Engineering Technology (IJRASET) ISSN: 2321-9653; IC Value: 45.98; SJ Impact Factor: 6.887 Volume 6 Issue IV, April 2018- Available at www.ijraset.com

[15] Suraj Shetty et al, “ Drone Operated Chemical Fertilizer Sprinkle" International Journal of Innovative Research in Science, Engineering and Technology (A High Impact Factor, Monthly, Peer Reviewed Journal)Visit: www.ijirset.com Vol. 7, Issue 3, March 2018 DOI:10.15680/IJIRSET.2018.0703093

[16] Hang Zhu et al, "Development of a PWM Precision Spraying Controller for Unmanned Aerial Vehicles" Journal of Bionic $\begin{array}{lllll}\text { Engineering } & 7 & (2010) & 276-283 & \end{array}$ 10.1016/S1672-6529(10)60251-X

[17] Yallappa D. et al, "Development And Evaluation Of Drone Mounted Sprayer For Pesticide Applications To Crops" 2017 IEEE global humanitarian technology conference (GHTC) 19-22 Ocb 2017

[18] R.Ilakiya et al," Design of UAV for urea spraying in agricultural field" International Research Journal of Engineering and Technology (IRJET)

[19] Fabrizio Sarghini et al" Analysis of Preliminary Design Requirements of a Heavy Lift Multirotor Drone for Agricultural Use" CHEMICAL ENGINEERING TRANSACTIONS VOL. 58, 2017.

[20] Vikram Puri et al "Agriculture drones: A modern breakthrough in precision agriculture" Journal of Statistics \& Management Systems (2017).

[21] Mr I. D. Pharne et al" AGRICULTURE DRONE SPRAYER" International journal of recent trends in engineering and research. Volume 04, Issue 03; March- 2018 [ISSN: 2455-1457]

[22] Bruno S. Faiçal et al "An adaptive approach for UAV-based pesticide spraying in dynamic Environments" Computers and Electronics in Agriculture 138 (2017) 210-223 Accepted 20 April 2017

[23] Madhu K N et al, "Design of QuadCopter for Pesticide spraying"

[24] Nitish Das et al," Agricultural Fertilizers and Pesticides Sprayers - A Review" IJIRST -International Journal for Innovative Research in Science \& Technology| Volume 1 | Issue 11 | April 2015

[25] P, V. S. R., \& Gorantla, S. R. (2019). Design and Modelling of anAffordable UAV Based Pesticide Sprayer in Agriculture Applications. 2019 Fifth International Conference on 
Electrical Energy Systems (ICEES).

doi:10.1109/icees.2019.8719237

[26] Karan Kumar Shaw , Vimalkumar R. "Design and Development of a Drone for Spraying Pesticides, Fertilizers and Disinfectants" International Journal of Engineering Research \& Technology (IJERT) Vol. 9 Issue 05, May-2020

[27] Rahul Desale et al, "Unmanned Aerial Vehicle For Pesticides Spraying”, IJSART - Volume 5 Issue 4 - APRIL 2019

[28] Vikrant Krishna Suryawanshi et al "Design \& Development of Agricultural Fertilizer Spraying Drone with Remote Controller and Autonomous Control with low weight Aluminium Alloy frame Structure." Journal of Remote Sensing GIS \& Technology Volume 5 Issue 2 DOI:http://doi.org/10.5281/zenodo.2631047

[29] Shaik.Khamuruddeen et al, "Intelligent Pesticide Spraying System using Quadcopter" International Journal of Recent Technology and Engineering (IJRTE) Volume-7, Issue-5S4, February 2019

[30] Matsuura, F., Fukumi, J., \& Fukuda, K. (2017). Research of crop-sprayer for dotted farmland using airflow induced by UAV. 201756 th Annual Conference of the Society of Instrument and Control Engineers of Japan (SICE). doi: $10.23919 /$ sice. 2017.8105593

[31] Tejas S. Kabra et al ," Design, Development \& Optimization of a Quad-Copter for Agricultural Applications" International Research Journal of Engineering and Technology (IRJET) Volume: 04 Issue: 07 | July -2017

[32] Wen, S., Han, J., Ning, Z., Lan, Y., Yin, X., Zhang, J., \& Ge, Y. (2019). Numerical analysis and validation of spray distributions disturbed by quad-rotor drone wake at different flight speeds. Computers and Electronics in Agriculture, 166, 105036. doi:10.1016/j.compag.2019.105036

[33] Y. Huang, W. C. Hoffmann, Y. Lan, W. Wu, \& B. K. Fritz. (2009). Development of a Spray System for an Unmanned Aerial Vehicle Platform. Applied Engineering in Agriculture, 25(6), 803-809. doi:10.13031/2013.29229

[34] R. Nivas et al Automatic Spraying of Fertilizers/Pesticides Using Drone IRE Journals | Volume 3 Issue 10 Apr 2020.

[35] Vihari, M. M., Nelakuditi, U. R., \& Teja, M. P. (2018). IoT based Unmanned Aerial Vehicle system for Agriculture applications. 2018 International Conference on Smart Systems and Inventive Technology (ICSSIT). doi:10.1109/icssit.2018.8748794

[36] Anken Thomas et al," Working Quality, Drift Potential and Homologation of Spraying Drones in Switzerland" M. Gandorfer et al.: Digitalisierungfür Mensch, Umwelt und Tier, Lecture Notes in Informatics (LNI), Gesellschaft fürInformatik, Bonn 2020

[37] ) Tang, Y., Hou, C. J., Luo, S. M., Lin, J. T., Yang, Z., \& Huang, W. F. (2018). Effects of operation height and tree shape on droplet deposition in citrus trees using an unmanned aerial vehicle. Computers and Electronics in Agriculture, 148, 1-7. doi:10.1016/j.compag.2018.02.026

[38] Qin, W., Xue, X., Zhang, S., Gu, W., \& Wang, B. (2018). Droplet deposition and efficiency of fungicides sprayed with small UAV against wheat powdery mildew. International Journal of Agricultural and Biological Engineering, 11(2), 27-32.

[39] Saddam Hussain et al (2019), “ Spray Uniformity Testing of Unmanned Aerial Spraying System for Precise Argo-Chemical Applications" Pak. J. Agri. Sci., Vol. 56(4), 2019. DOI:10.21162/PAKJAS/19.8594 